\title{
Formulating strategies for development of lontar sugar industry in Rote Ndao District, East Nusa Tenggara Province, Indonesia
}

\author{
FAHRIZAL ${ }^{1, v}$, JASMAN $^{2}$, YEHESKIAL NGGANDUNG $^{3}$, KARTIWAN $^{4}$ \\ ${ }^{1}$ Department of Mechanical Engineering Education, Faculty of Teacher Training and Education, Universitas Nusa Cendana. Jl. Adisucipto, Penfui, \\ Kupang 85001, East Nusa Tenggara, Indonesia. Tel./fax.: +62-380-881580, `email: fahrizal@ staf.undana.ac.id \\ ${ }^{2}$ Department of Chemical Education, Faculty of Teacher Training and Education, Universitas Nusa Cendana. Jl. Adisucipto, Penfui, Kupang 85001, East \\ Nusa Tenggara, Indonesia \\ ${ }^{3}$ Department of Economic Education, Faculty of Teacher Training and Education, Universitas Nusa Cendana. Jl. Adisucipto, Penfui, Kupang 85001, East \\ Nusa Tenggara, Indonesia \\ ${ }^{4}$ Department of Food Technology, Politeknik Pertanian Negeri Kupang. Jl. Prof. Dr. Herman Johanes, Lasiana, Kelapa Lima, Kupang 85228, East Nusa \\ Tenggara, Indonesia
}

Manuscript received: 1 September 2019. Revision accepted: 31 October 2019

\begin{abstract}
Fahrizal, Jasman, Nggandung Y, Kartiwan. 2019. Formulating strategies for development of lontar sugar industry in Rote Ndao Regency, East Nusa Tenggara Province. Trop Drylands 3: 41-48. Lontar (Borassus flabellifer) is a kind of palm tree utilized by home industries in Rote Ndao District, East Nusa Tenggara Province, for making sugar. Generally, the lontar sugar produced is molded sugar and crystal sugar. However, the home industries generally produce molded sugar more than the crystal one (which has better price), missing the opportunity to obtain higher benefits from lontar utilization. This research aimed to formulate and determine the priority of strategies for development of the crystal sugar industry in Rote Ndao District. Depth interview techniques, observation, and literature studies were used to identify the strategic factors, which were then presented in the form of EFE and IFE matrix. The value of each factor was obtained from pairwise comparison method. SWOT analysis resulted in 5 strategies to be applied with priority order of the strategies are: (i) development of crystal sugar industry by partnership system, (ii) application of technology for improving quality and quantity of the product, (iii) training of Good Manufacturing Practice and Good Agricultural Practice, (iv) institutional assistance from the related department, and (iv) increasing of marketing networks.
\end{abstract}

Keywords: Crystal sugar industry, IFE, EFE, SWOT

\section{INTRODUCTION}

Lontar (Borassus flabellifer) is a kind of palm tree from Arecaceae family, known to well grow on dryland at altitude of $100-500 \mathrm{~m}$ above sea level with annual precipitation of $1000-2000 \mathrm{~mm}$ and 4-8 dry months (Tambunan 2010). In Indonesia, this plant can be found abundantly in East Nusa Tenggara (ENT) Province in the districts of Kupang, Sabu Raijua, West South Sumba, and Rote Ndao. Among them, the most potential growing area is Rote Ndao District with an estimated area of 10,409 ha (Forest Research and Development Center, Ministry of Forestry, Republic of Indonesia 2010).

The main product of the lontar utilized by the community is sap (a kind of liquid released from stem of the palm). The sap may be directly consumed as a sweet fresh drink, or being traditionally fermented to make alcoholic drink called sopi. The sap was also processed by farmers to make syrup, molded sugar, and crystal sugar. Among these products, molded sugar is the most frequently produced by the community, while crystal sugar is only produced in a limited amount. Besides the lontar tree, crystal sugar may also be produced from other palm trees, for example, coconut tree and aren (Arenga pinnata L.) tree. A large amount of crystal sugar, including from aren, is produced by home industry in the provinces of Central
Java, East Java, West Java, West Sumatra, and South Sulawesi (Aliudin et al. 2011; Evalia 2015; Sugiyowati et al. 2015; Irmawati et al. 2015; Subekti et al. 2018).

Crystal sugar from lontar tree is one of derivated products with a high economic value and great potentials to be developed. This is because the product has some advantages over the other, for example, higher price, easier to be dissolved, easier to be mixed with other ingredients, easier to be packed and transported, and has a specific taste and aroma (Mustaufik and Dwiyanti 2007). Furthermore, crystal sugar may also be made from molded sugar by reprocessing technique (Mulyadi 2011). Considering the advantages, lontar crystal sugar appears to have high potential to be developed as prime product with high competitive value as high as crystal sugar from aren and coconut trees. Recently, coconut and aren crystal sugar are produced to meet both local and export markets (Evalia 2015).

Crystal sugar in ENT Province is produced by small home industry in District of Rote Ndao. Small scale production employs 3-4 employers, and every home industry owns about 12 to 30 lontar trees. Lontar sugar is usually made during the dry season, from April to the end of November every year. In this period, lontar trees produce flowers after the wet season. Along the period, sap productivity of lontar trees varies with the peak season 
occurring from September to October. Generally, the average sap productivity is 12.5 liters or about $10 \mathrm{~kg}$ per tree per day. Yield of crystal sugar from this sap is $13.8 \%$ (Fahrizal et al. 2017), meaning that to produce $13.8 \mathrm{~kg}$ crystal sugar requires $100 \mathrm{~kg}$ of sap.

Production of crystal sugar is still performed using simple technologies passed down from old generation to younger generation. This technique still uses firewood as fuel, and then the product is sold at traditional markets. The crystal sugar is made just to meet the need of local community. There is no business unit organizing the product for broader marketing, for example, export to neighboring islands or other countries. The sugar is sold in batch in a volume base, not in weight base. There is no packaging of the product, thus, it could not be stored for a long time and the marketing range is limited. Sap productivity may be increased if good crop maintenance is applied for the lontar trees. Income of the industry may also be increased by exploiting the by-product obtained during the production period.

Not all of the sap produced is used to make crystal sugar; most of the sap produced is used to make molded sugar. Crystal sugar is usually produced at the end of the production season (October-November). This is based on the consideration that crystal sugar has a longer shelf life, so that it functions as the source of cash-saving and can be marketed after the production season. Conversely, molded sugar has a short shelf life, so the crystal sugar industry chooses to sell them directly rather than store them.

The lontar sugar industry has an important value in improving the welfare of all parties involved and its potential can be optimized. Nonetheless, the development of the crystal sugar industry faces many obstacles that must be addressed because of a number of inhibiting factors. However, it is undeniable that there are also a number of supporting factors. Therefore, there is a need for strategy formulation in its development.

The formulation of the strategy must be adjusted to the characteristics and problems of the industry concerned. The development strategy will have an effect on increasing competitiveness, increasing revenue and business sustainability, and improving regional economies. The purpose of this study was to formulate and determine the priority of alternative strategies in developing home industry of lontar palm sugar in Rote Ndao District, East Nusa Tenggara Province.

\section{MATERIALS AND METHODS}

\section{Data collection}

The research was carried out in the Home Industry of Crystal Sugar, Duadolu Village and Tualima Village, Rote Barat Daya District, Rote Ndao District, East Nusa Tenggara Province. Both of these villages are production centers of molded sugar and crystal sugar in Rote Ndao District. Data collection used literature study methods, field observations, interviews, filling out questionnaires and depth interviews with a number of experts who are considered to have knowledge of crystal sugar. The collected data was then analyzed qualitatively and quantitatively.

\section{Methods \\ SWOT analysis}

SWOT Analysis (Strengths, Weaknesses, Opportunities, and Threats) is a tool commonly used for analyzing external and internal environments simultaneously in order to attain a systematic approach and support for a decision (Ozdemir and Demirel 2018; Goroner et al. 2012). In this study, SWOT analysis was used to analyze internal and external environmental factors that influence the development of the lontar sugar home industry in formulating strategies. To arrive at the goal of strategy formulation, identification of internal and external environmental factors that influence the development of the lontar sugar home industry was identified. Identification of internal strategic factors included aspects of strengths and weaknesses, as well as external strategic factors covering aspects of opportunities and threats. The results of identification of all factors were then summarized in the form of IFE (Internal Factor Evaluation) matrix, and EFE (External Factor Evaluation) matrix.

A pairwise comparison method was used to give weight to internal and external factors. The weighted strategic factors were obtained by determining the value of each strategy relative to the total values of all strategic factors (Arkeman et al. 2015; Triantaphyllou 1995). After that, the weight was normalized to get the total weight equals unity.

Rating of the IFE matrix shows the level of strategic factors strengths and weaknesses that influence the development of the crystal sugar home industry. While determining the rating on the EFE matrix was based on the ability of the crystal sugar home industry in reaching the opportunities and the magnitude of threats that can affect their existence. IFE and EFE matrix ratings were determined by giving values 1 to 4 for each factor with reference to the description in Table 1 and Table 2.

Table 1. Description of rating determination on the IFE matrix

\begin{tabular}{cl}
\hline Value & Description \\
\hline 4 & $\begin{array}{l}\text { If the power factor is considered to have a very strong influence and if the weakness factor is considered to have a very weak } \\
\text { effect (poor) }\end{array}$ \\
3 & $\begin{array}{l}\text { If the strength factor is considered to have a strong influence and if the weakness factor is considered to have a strong influence } \\
2\end{array}$ \\
$\begin{array}{l}\text { If the strength factor is considered to have a moderate effect and if the weakness factor is considered to have a moderate effect } \\
\text { influence }\end{array}$
\end{tabular}


Table 2. Description of rating determination on EFE matrix

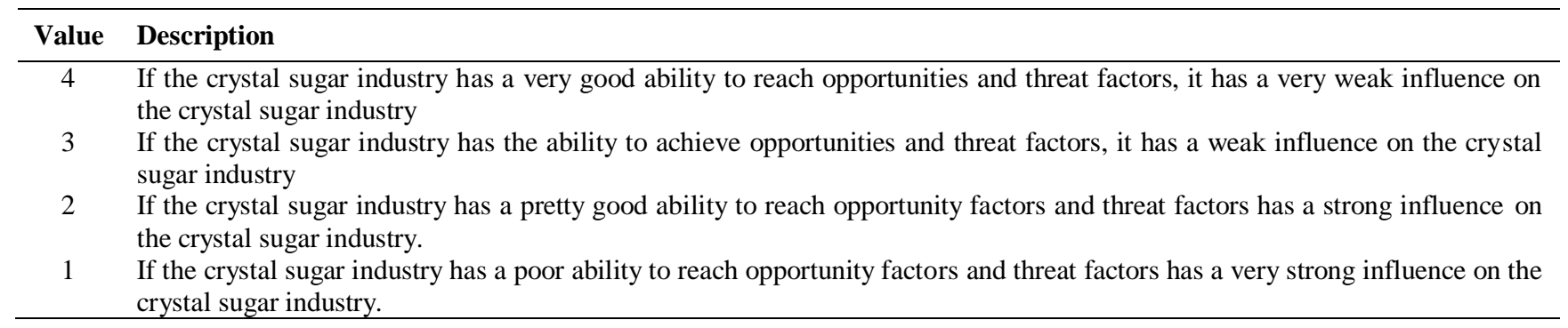

Table 3. Saaty's scale 1-9 used for pairwise comparison of decision making prioritization strategy

\begin{tabular}{cll}
\hline Saaty's score & Definition & Description \\
\hline 1 & Equal dominance & Two elements are of equal importance in regard to the higher-level objective \\
3 & Weak dominance & Experience or judgment slightly favor one element over other \\
5 & Strong dominance & Experience or judgment considerably favor one element over other \\
7 & Very strong dominance & Very strong dominance of one element over the other \\
9 & Absolute dominance & Dominance of the highest degree \\
$2,4,6,8$ & Intermediate values & $\begin{array}{l}\text { They are used to demonstrate compromise intermediate values of priorities between } \\
\text { the above-listed score 1,3,5,7 and } 9\end{array}$ \\
& &
\end{tabular}

Source: Dlbokic et al. (2017)

\section{Internal-external matrix analysis}

The strategy formulation in the development of the lontar crystal sugar industry in Rote Ndao District was used in SWOT analysis. Internal factors that describe strengths and weaknesses were summarized in the IFE matrix, while environmental factors that reflect opportunities and threats were summarized in the EFE matrix. The results of the assessment of internal and external factors in the IFE matrix and EFE matrix obtained the total score of each factor. The results of the assessment were used to determine the position of the lontar crystal sugar industry in the SWOT diagram (Rangkuti 2006; Sugiyowati et al. 2015).

\section{Alternative crystal sugar industry development strategy}

The strategic factors presented in the IFE and EFE matrix were then presented in the SWOT matrix to determine alternative strategies. Based on the SWOT matrix, four main strategies can be arranged, namely: SO strategies, WO, ST and WT strategies (Dlbokic et al. 2017; Rangkuti 2006). SO strategy is a strategy created by using the company's internal strength to take advantage of external opportunities. The WO strategy is created to correct internal weaknesses and use external opportunities. The ST strategy was made to anticipate external threats by using internal strengths, and the WT strategy was made to deal with weaknesses and threats that could not be dealt with using existing strengths and opportunities.

\section{Prioritization of strategies}

One of the major constraints in prioritization of strategies generated based on the SWOT matrix is the fact that the importance of each factor in the decision making cannot be quantitatively measured, which makes it difficult to assess which factor has the greatest impact on individual strategies. Strategy priorities were determined based on the assessment of a number of experts on the importance of each factor in the SWOT matrix using pairwise comparison method. One method used to determine priority order is Analytical Hierarchy Process (AHP). It has been used to determine the priority order of alternative strategies, for example, Setiyadi et al. (2011) and Luksmanto (2014). AHP and fuzzy approaches integrated have also been used for the same purpose, for example, Goroner et al. (2012), Hadavi and Mirabi (2017) and Karatop et al. (2018). According to Saaty (1983), for various problems, a scale of 1 to 9 is the best scale in expressing opinions. The values and definitions of qualitative opinions from the current comparison scale are presented in Table 3.

This study used a system approach (Wasson 2006), which is characterized by a number of stages that are systematic, logical and structured. The stages of the study consisted of identifying a number of internal and external factors, then proceed with a SWOT analysis. The final stage is weighing all alternatives to get priority orders. The research framework elaborated at the research stage is presented in Figure 1. 


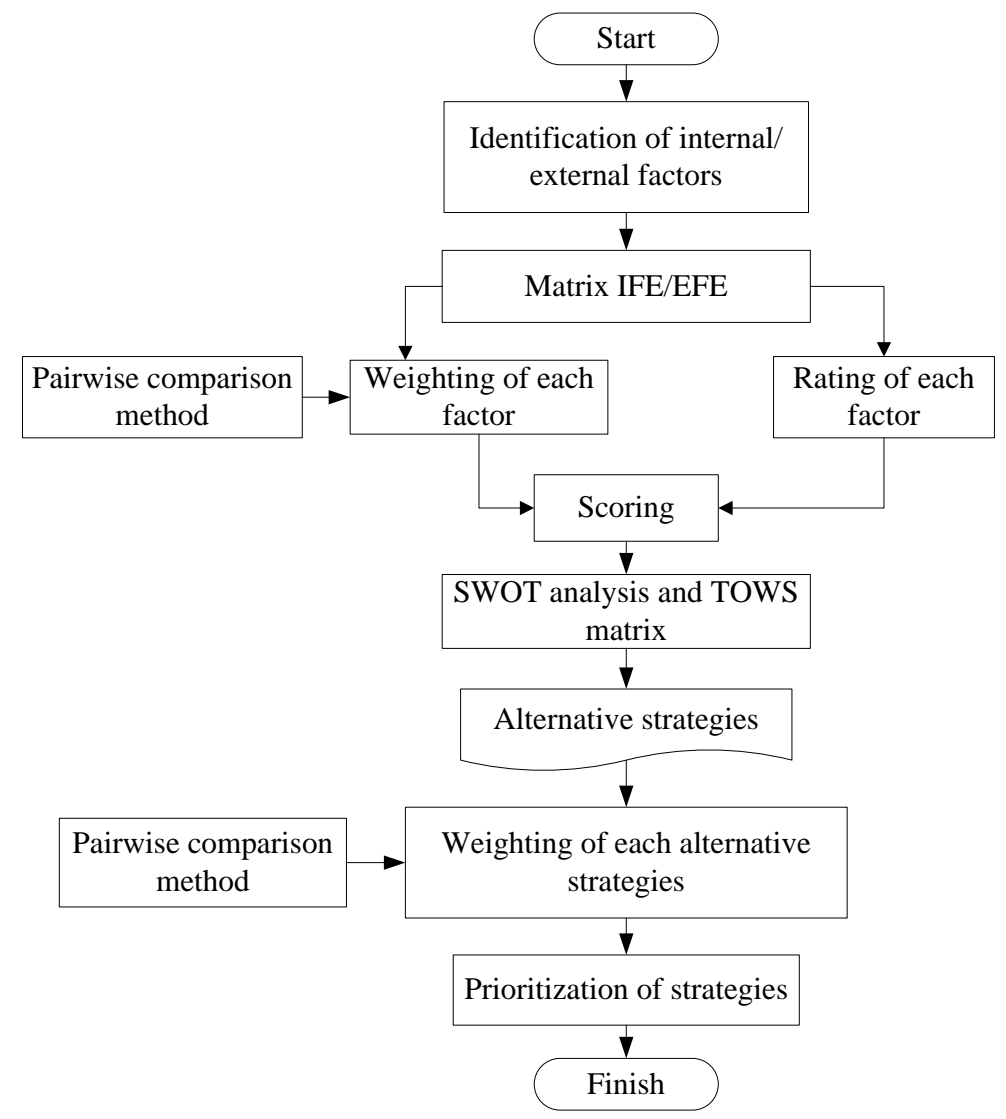

Figure 1. The research framework and stages applied in this study.

\section{RESULTS AND DISCUSSION}

\section{Formulation of the lontar crystal sugar industry development strategy}

In evaluating the factors that will affect the development of the lontar crystal sugar home industry in Rote Ndao District, we identified internal strategic factors including strengths and weaknesses, as well as external strategic factors including opportunities and threats. The strength factors are as follows: (i) Characteristics of lontar sugar. Lontar sugar has a distinctive taste, sweeter and browner color than the other sugar such as coconut sugar. These advantages cause lontar sugar more preferred by consumers. (ii) Naturally processed and environmentally friendly. No machines or chemicals are used in making lontar sugar as compared to that in the manufacture of cane sugar. As lontar sugar is processed naturally, it contains no harmful chemicals such as preservatives, dyes, thickeners, and other chemicals, and produces no waste that can damage the environment. (iii) Sugar levels are lower than cane sugar. Lontar sugar has lower levels of glymax compared to cane sugar. It is good for health, especially for people who suffer from diabetes mellitus. (iv) Local labor is sufficiently available. Processing of lontar sugar involves family workers. Processing locations are generally in rural areas so they are able to absorb a large potential of labor. (v) Availability of raw materials. Lontar sugar is made from the sap produced by lontar plants. These plants grow naturally in the yard or community field. Although not all communities work as sugar makers, almost all families maintain this plant. Thus, the availability of raw material in the form of sap is very high for the needs of crystal sugar industries.

Besides having internal factors that provide the strength of the lontar sugar industry in Rote Ndao District, there are also weaknesses factors, namely: (i) Traditionally produced. Lontar sugar is produced using simple technology, especially in the process of filtering the sap and cooking process. Filtering the sap has not yet used a filter that meets the standard method, which causes the sugar to still contain lots of impurities (Fahrizal et al. 2017). Cleanliness of production equipment has not been well done. The use of firewood causes high costs and the fire smoke pollutes the kitchen. (ii) Produced individually by households. Crystal sugar is made by families with a workforce of 2-3 people. There is no partnership, for example, between the sap producers and the craftsman. The sap producer is also a sugar crafter. (iii) Availability of raw materials depends on the season. Making of sugar depends on the availability of sap. Lontar trees produce sap for only about 7 to 8 months every year, i.e. April to November every year. (iv) There are no marketing networks. The crystal sugar produced is directly marketed in traditional markets that generally take place on Wednesdays and Saturdays at Busalanga Market. There are no collectors or wholesalers that accommodate their sugar production. (v) 
Limited market. Crystal sugar has not been packaged, and is also not yet labeled and certified by Badan Pengawas Obat dan Makanan (BPOM), so its market is limited to traditional markets. BPOM is a non-ministerial government agency that conducts government affairs in the field of drug and food control. (vi) Product quality is still low. The product was dried not using by oven drying, so the water content was still high, ranging from 7 to 8 percent, causing a low shelf life of fewer than 4 months. Crystal sugar with $3 \%$ water content has a shelf-life of up to 8 months. (vii) Production quantity is not stable. The amount of sugar production is not fixed and is very dependent on the amount of sap. (viii) The quality of human resources is still low. Knowledge and skills in making the crystal sugar are not obtained from formal education or training, but just passed down from generation to generation. Therefore, the application of good processing technology such as drying and packaging technology has not been applied. (ix) Supporting institutions are lacked. There are no institutions such as Village-Owned Enterprises (BUMDES) or cooperatives that provide a platform for the development of crystal sugar production.

Identification of external factors obtained seven opportunity factors, as follows: (i) Culture of local residents. Making lontar sugar is the livelihood of the local population and has been going on for a long time from generation to generation. Lontar sugar is a very important source of food for the people in Rote Ndao. Therefore, making lontar sugar is not only a source of income but also for necessity of life. (ii) The increasing demand for organic sugar products. Demand for organic sugar including lontar sugar is increasing, especially for home consumption and food industry. (iii) Increased added value from processing lontar crystal sugar. Lontar sap can be consumed directly in the form of fresh drinks or flavor enhancers. However, the economic value is lower than that of crystal sugar. (iv) Local government support. The regional government provides the opportunity for the home industry of lontar sugar to sell its products not only in traditional markets, but also at ferry ports, and some also were sold in shops. (v) The waste of firewood after cooking sugar can be used for making charcoal. The remaining coal from combustion can be made of charcoal and sold as an additional source of income. (vi) The skill of making sugar products is inherited from generation to generation. Sugar making skills are not obtained through an internship or training process, but are obtained from the family environment. (vii) Development of science and technology. The technology of making sugar, including lontar sugar, continues to increase. This can encourage the use of more efficient technology in making lontar sugar.

Besides having external factors that provide opportunities for the lontar crystal sugar industry, there are also threat factors, namely: (i) Low and fluctuating production capacity. This causes the consumer demand cannot be fulfilled. (ii) Price competition with cane sugar products. The price of lontar sugar is relatively more expensive compared to cane sugar. This is a consideration of consumers, especially the food industry because it will cause an increase in production costs. (iii) Cultivation of lontar plant has not been done. Lontar plants grow naturally in the yard or in the community garden. Growing in groups and irregularly. This is because young plants that grow are derived from seeds that fall from trees. Although lontar cultivation techniques have been discovered (Bernhard 2017) and involved plant selection, planting, and maintenance, the community has not yet practiced them. (iv) Product demands according to standards. The lontar sugar must meet the crystal sugar quality requirements by referring to the quality standards set by the National Standardization Agency of Indonesia (1995). Not fulfilling the quality requirements causes the lontar crystal sugar fall short to meet the requirements to be marketed at a wider level. (v) The potential of lontar sap for alcoholic drinks and bioethanol. Lontar sap as a raw material for crystal sugar can also be made into alcoholic beverages. The higher price of alcoholic beverages causes some people to prefer to make this product instead of crystal sugar.

Internal factors that represent the strengths and weaknesses of developing the lontar crystal sugar home industry namely the weight of each factor, rating score, and total score, are summarized in the IFE matrix presented in Table 4. Whereas, environmental factors that reflect opportunities and threats are summarized in the matrix EFE and presented in Table 5.

\section{Determination of alternative and priority of the strategy for the development of lontar sugar industry}

There are four main approaches used to determine alternative strategies, namely: SO, WO, ST, and WT strategies. Based on the SO strategy, there were 3 alternatives, namely the development of the partnership of sugar industry, product and packaging diversification, and the utilization of combustion residual charcoal as a source of income. The WO strategy obtained 3 alternatives, namely the application of technology to improve the quality and quantity of production, institutional assistance from related agencies and improve marketing networking. ST strategy suggests 2 alternatives, namely training in Good Manufacturing Practice and Good Agricultural Practice and providing financial assistance to increase production. WT strategy recommends 2 alternatives, namely increasing commitment and cooperation between all stakeholders and marketing targets on traditional markets. Alternative strategies have different levels of importance or weight, so the order of priorities needs to be determined. The order of alternative priorities is based on the respective weights as shown in Table 6. 
Tabel 4. Matrix of IFE (Internal Factor Evaluation)

\begin{tabular}{|c|c|c|c|}
\hline Internal factors & Weight & Rating & Score \\
\hline \multicolumn{4}{|l|}{ Strength } \\
\hline Characteristic of lontar sugar & 0.064 & 3 & 0.193 \\
\hline Processed naturally and environmentally friendly & 0.060 & 3 & 0.180 \\
\hline Sugar levels are lower than cane sugar & 0.098 & 3 & 0.296 \\
\hline Local labor is available & 0.153 & 4 & 0.612 \\
\hline Availability of raw materials & 0.123 & 4 & 0.494 \\
\hline Total & & & 1.775 \\
\hline \multicolumn{4}{|l|}{ Weakness } \\
\hline Traditionally produced & 0.046 & 3 & 0.140 \\
\hline Produced individually by households & 0.083 & 1 & 0.083 \\
\hline Raw materials depend on the season & 0.053 & 2 & 0.107 \\
\hline There is no marketing networks yet & 0.057 & 1 & 0.057 \\
\hline Limited market share & 0.035 & 1 & 0.035 \\
\hline Product quality is still low & 0.046 & 1 & 0.046 \\
\hline Production quantity is not stable & 0.041 & 2 & 0.082 \\
\hline The quality of human resources is still low & 0.085 & 1 & 0.085 \\
\hline Supporting institutions are lacked & 0.050 & 2 & 0.101 \\
\hline Total & & & 0.736 \\
\hline
\end{tabular}

Source: Primary data processed (2019)

Tabel 5. Matrix of EFE (External Factor Evaluation)

\begin{tabular}{|c|c|c|c|}
\hline External factors & Weight & Rating & Score \\
\hline \multicolumn{4}{|l|}{ Opportunity } \\
\hline Local culture & 0.096 & 4 & 0.384 \\
\hline The increasing demand for organic sugar products & 0.069 & 3 & 0.207 \\
\hline Increased added value from the processing of lontar sap & 0.085 & 3 & 0.256 \\
\hline Local government support & 0.092 & 4 & 0.370 \\
\hline The waste produced by cooking can be used to make charcoal as a source of income & 0.045 & 2 & 0.091 \\
\hline The skill of making crystal sugar is inherited from generation to generation & 0.068 & 3 & 0.204 \\
\hline Development of science and technology & 0.042 & 3 & 0.127 \\
\hline Total & & & 1.639 \\
\hline \multicolumn{4}{|l|}{ Threat } \\
\hline Low production capacity and volatility & 0.136 & 2 & 0.273 \\
\hline Price competition with sugar cane products & 0.059 & 3 & 0.177 \\
\hline Lontar cultivation has not been done well & 0.103 & 3 & 0.310 \\
\hline Product demands according to standards & 0.124 & 2 & 0.248 \\
\hline Conversion of lontar sap into bioethanol & 0.076 & 2 & 0.153 \\
\hline Total & & & 1.161 \\
\hline
\end{tabular}

Table 6. Results of alternative weight calculation strategies

\begin{tabular}{lll}
\hline No. & Alternative strategies & Weight \\
\hline 1 & Development of the crystal sugar industry partnership system & 0.154 \\
2 & Application of technology to improve the quality and quantity of production & 0.147 \\
3 & Good Manufacturing Practice training and Good Agricultural Practice & 0.136 \\
4 & Institutional assistance from related agencies & 0.104 \\
5 & Improve network marketing & 0.101 \\
6 & Product and packaging diversification & 0.099 \\
7 & Utilization of combustion residual charcoal as a source of income & 0.079 \\
8 & Providing financial assistance to increase production & 0.065 \\
9 & Increased commitment and cooperation between all stakeholders & 0.063 \\
10 & Target marketing in traditional markets & 0.048 \\
\hline
\end{tabular}

Source: Primary data processed (2019) 


\section{Discussion}

Based on Table 4, the total score of the strength factor is 1.775 and the total score in the weakness factor is 0.736 . This shows that the development of a lontar crystal sugar home industry has greater strength than its weakness with a difference of 1.039. Based on Table 5, the total score for the opportunity factor is 1.639 and the total score for the threat factor is 1.161 , indicating that the opportunity for the lontar sugar industry is greater than the threat with a difference of 0.6. The difference value is then plotted in the SWOT diagram analysis.

According to Rangkuti (2006), SWOT diagrams consist of 4 quadrants that indicate the position of existing strategies, namely quadrant I: aggressive strategy, quadrant II: diversification strategy, quadrant III: improvement strategy, quadrant IV: survival strategy. Based on the analysis of the diagram, it is known that the development of the home industry of lontar crystal sugar is in quadrant I. This shows that the lontar sugar industry is in a very favorable situation because it has the strength and opportunity that can be utilized optimally. Thus, the strategy that should be used is a strategy that supports aggressive growth by utilizing existing opportunities (Rangkuti 2006; Sugiyowati et al. 2015).

Based on Table 5, it can be seen that the strategy for developing the lontar crystal sugar industry in the partnership system is the strategy with the highest weight value. The partnership system means that the crystal sugar industry can consist of beneficiaries as sapper suppliers, processing industries as processors, collectors or cooperatives and end consumers. In this partnership system, the small lontar sugar industry functions more as a processor that process raw material into finished product. The raw material for sap is obtained from suppliers. Product marketing is carried out by cooperatives, collectors, or retailers. Through this partnership system, the crystal sugar industry is easier to get capital assistance, training, mentoring, and supervision from related parties, so that the quality and quantity of products are guaranteed, as well as a wider marketing range. To carry out this strategy, clear rules, clear agreements, and strong commitment among all parties involved to achieve the goal are needed.

Another alternative strategy that gets priority is the application of technology to improve the quality and quantity of production. The technology is applied at the level of on-farm and off-farm. At the level on-farm, lontar sugar producers must apply good cultivation techniques $($ Good Agricultural Practice $=$ GAP $)$ to increase the yield such as planting, weeding and fertilizing. At the off-farm level, lontar sugar producers must implement good manufacturing techniques (Good Manufacturing Practices = GMP) such as room handlers, equipment cleanliness, and production sites. The critical point in making sugar generally lies in the treatment of sap before being processed into sugar (Marsigit 2005). A number of factors can cause the lontar sap to be damaged or fermented, which results in a decrease in the quantity and quality of sugar products. Therefore GAP and GMP training is an important strategy to improve the knowledge and skills of lontar sugar producers.

Support from the local government or related agencies is very important in the development of the crystal sugar industry. GAP and GMP training can be facilitated by the government or related agencies. Institutional assistance in the form of establishing cooperatives can be facilitated by the local government or related agencies. Cooperatives can function to accommodate production products at mutually agreed prices, as well as a forum for expanding market share and marketing networks, such as in the food industry, supermarkets, inter-island traders, and or exporters.

This research can be continued by using a combination method of SWOT and multiple criteria decision-making approach, for example, AHP (Analytical Hierarchy Process) or fuzzy logic framework with the AHP method to effectively analyze cases having uncertainty. Furthermore, any multiple criteria decision-making technique may be applied instead of the AHP in order for the results could be compared.

\section{ACKNOWLEDGEMENTS}

The research team would like thank to the Institute for Research and Community Service of University of Nusa Cendana and Directorate of Research and Development of the Ministry of Research and Technology of the Republic of Indonesia for funding this research through the scheme of applied research year 2019, contract number 35/UN.19/PL/2019.

\section{REFERENCES}

Aliudin S, Sariyoga D, Anggraini. 2011. Efisiensi dan pendapatan usaha gula cetak. Jurnal Agro Ekonomi 28 (1): 73:85. [Indonesian]

Arkeman Y, Herlinawati T, Wibawa DS, Adinegoro H. 2015. Formulating strategies to improve food safety of bakery small-medium enterprises through good manufacturing practice. J Teknologi Industri Pertanian 25 (1): 43-51. [Indonesian]

Bernhard MR. 2017. Budidaya Lontar (Borassus sundaicus Becc). Buletin Palma 32: 81-91. DOI: 10.21082/bp.v0n32.2007.81-91 [Indonesian]

Dlbokic M, Nikolic D, Djordjevic P, Panic M, Zivkovic Z. 2017. SWOTAHP model for prioritization of strategies for development of viticulture in Jablanica District-Serbia. Strategic Manag 2 (1): 44-52.

Evalia NA. 2015. Strategi pengembangan agroindustri gula semut aren. J Manajemen Agribisnis 12 (1): 57-67. DOI: 10.17358/JMA.12.1.57 [Indonesian]

Forest Research and Development Center Ministry of Forestry Republic of Indonesia. 2010. Lontar (Borassus flabellifer) sebagai Sumber Energi Bioetanol Potensial. Forest Research and Development Center, Bogor. [Indonesian]

Fahrizal, Yeheskial NG, Kartiwan. 2017. Optimasi produksi gula cetak dan gula semut lontar terintegrasi dengan metode linear programming. Prosiding Seminar Nasional Hasil Penelitian (SNHP)VII. Universitas PGRI, Semarang. 26 Oktober 2017. [Indonesian]

Goroner A, Toker K, Ulucay K. 2012. Application of combined SWOT and AHP: A case study for a manufacturing firm. Procedia-Soc Behav Sci 58: 1525-1534. DOI: 10.1016/j.sbspro.2012.09.1139

Hadavi MH, Mirabi VH. 2017. Prioritizing SWOT factors using hybrid model of BSC, SWOT, Fuzzy AHP and Fuzzy TOPSIS techniques developed for use in large Iranian Commercial Bank. Int Academic J Business Manag 4 (2): 53-70.

Irmawati, Syam H, Jamaluddin. 2015. Analisis kelayakan finansial dan strategi pengembangan usaha industri rumahan gula semut (palm 
sugar) dari nipah di Kelurahan Pallantikang. J Pendidikan Teknologi Pertanian 1: 76-94. DOI: 10.26858/jptp.v1i1.5147 [Indonesian]

Karatop B, Kubat C, Uygun O. 2018. Determining the strategies on Turkish automotive sector using fuzzy AHP based on the SWOT analysis. Sakarya Univ J Sci 22 (5): 1314-1325. DOI: 10.16984/saufenbilder.298875

Luksmanto H. 2014. Implementation of SWOT-FAHP method to determine the best strategy on development of traditional shipyard in Sumenep. Acad Res Int 5 (5): 56-67.

Marsigit W. 2005. Penggunaan bahan tambahan pada nira dan mutu gula aren yang dihasilkan di beberapa sentra produksi di Bengkulu. J Penelitian UNIB 9 (1): 42-48. [Indonesian]

Mustaufik, Dwiyanti H. 2007. Rekayasa pembuatan gula kelapa krista yang diperkaya dengan vitamin A dan uji preferensinya kepada konsumen. Research Report. Department of Agricultural Technology, Universitas Jenderal Soedirman, Purwokerto (unpublished) [Indonesian]

Mulyadi AF. 2011. Studi kelayakan pendirian unit pengolahan gula semu dengan pengolahan sistem reprosesing pada skala industri menengah di Kabupaten Blitar. Proceeding Lokakarya Nasional Pemberdayaan Potensi Keluarga Tani untuk Pengentasan Kemiskinan. Malang, 6-7 July 2011. [Indonesian]

National Standardization Agency of Indonesia. 1995. Standar Nasional Indonesia Gula Kelapa Kristal SII 0268-85. National Standardization Agency of Indonesia, Jakarta. [Indonesian]
Ozdemir Y, Demirel T. 2018. Prioritization of tourism strategies in Turkey using a SWOT-AHP analysis. Int J Business Ind Marketing 3 (2): $34-45$.

Rangkuti F. 2006. Analisis SWOT Teknik Membedah Kasus Bisnis. Gramedia Pustaka Utama, Jakarta. [Indonesian]

Saaty TL. 1983. Decision Making for Leader: The Analytical Hierarchy Process for Decision in Complex Word. RWS Publication, Pittsburg. DOI: $10.1007 / 978-1-4613-2805-612$

Setiyadi S, Amar K, Aji T. 2011. Penentuan strategi sustainability usaha pada UKM kuliner dengan menggunakan metode SWOT-AHP. J Ilmiah Teknik Industri 10 (2): 68-77. [Indonesian]

Sugiyowati L, Karno, Ekowati T. 2015. The development strategy of palm sugar agroindustry in Kendal Regency. Agromedia 33 (1): 1-12.

Subekti T, Hasanah, U, Windari I. 2018. Analisis usaha industri rumah tangga gula semut organik di Desa Hargorojo Kecamatan Bagelen Kabupaten Purworejo. Surya Agritama 7 (2): 66-78. [Indonesian]

Triantaphyllou E, Stuart HM. 1995. Using the analytic hierarchy process for decision making in engineering applications: some challenges. Int J Indust Eng: Appl Pract 2 (1): 35-44.

Tambunan P. 2010. Potensi dan kebijakan pengembangan lontar untuk menambah pendapatan penduduk. Jurnal Analisis Kebijakan Pertanian 1 (1): 27-45. DOI: $10.20886 /$ jakk.2010.7.1.27-45 [Indonesian]

Wasson CS. 2006. System Analysis, Design and Development Concept, Principles and Practice. John Wiley \& Sons, Inc., Hoboken New Jersey. 